\title{
A Comparison Of Traditional And Blended Learning In Introductory Principles Of Accounting Course
}

Chan Du, University of Massachusetts Dartmouth, USA

\begin{abstract}
This paper examines whether a blended course that introduces lower-level education online learned by students before they come into class and after class online assignments and online discussions enhances student performance for an introductory principles of accounting course over the period 2009-2010. The blended course design includes (1) before-class online quizzes, (2) after-class online homework assignments and online quizzes, (3) after-class comments postings, and (4) company case and project online postings. The regression results show that the above designed blended course improves the student final examination/course performance through in-depth in class activities after controlling for prior GPA, math grade, gender, transfer, homework grade, online quiz grade, and in-class exercise grade.
\end{abstract}

Keywords: Blended Instruction; Web-based; Bloom’s Taxonomy; Principles of Accounting

\section{INTRODUCTION}

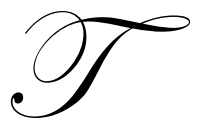

his paper examines whether a blended course that introduces lower-level education online learned by students before they come into class will enhance student performance as compared to traditional course. Blended course combines traditional delivery with online teaching resources to enhance the quality of the learning experienced by its students. It has been argued that, on the pedagogical level, blended learning allows faculty to integrate the best of the online learning environment with the best of the face-to-face learning environment. There have been some studies that compare the traditional and blended teaching models on accounting learning. These studies find mixed results. For example, some studies report no significant difference between traditional teaching model and blended teaching model, e.g., Keller et al. (2009). On the other hand, other studies find significantly positive student performance for blended course, e.g., Dowling et al. (2003), Potter and Johnston (2006), and Jones and Chen (2008).

Bloom's Taxonomy classifies the education objective into six categories: Knowledge, Comprehension, Application, Analysis, Synthesis, and Evaluation (Bloom, 1956). Shibley (2009) suggests that blended learning can create ways for students to learn before class, during class and after class. For example, the instructor can take the lower-level content and let students to think about it before they come into the classroom, i.e., ask the students to read the PowerPoint slides and textbook before they come to class and work on a short online quiz on the materials. The before-class learning process makes extra time available during class to engage students with activities, discussions, and group work to reach the higher-level Bloom's Taxonomy. The author suggests that after class design is to create assignments that encourage students to continue their contact with the material.

This paper provides additional evidence on the design and student performance associated to blended course. In particular, the paper proposes that a blended course that is designed to incorporate before-class quiz and after-class assignment and online discussion (1) improves the student performance directly and (2) improves the student performance through in-class activities when compared to traditional course. 
The motivations of the study are two-folds: (1) lower level study of Bloom's Taxonomy such as Knowledge and Comprehension can be learned by students themselves, which leaves class time for higher level of Taxonomy such as Application, Analysis and Evaluation through instructor-lead class discussion and more complicated case and problem solving, and (2) to increase students learning interests. The objective of the study is to increase students' responsibility in the learning process. To achieve the objective, the students are given beforeclass online quizzes that they should complete after reading the posted PowerPoint slides and textbook before they come to class. They are also required to post after-class comments on the discussion board on what they think as the most confusing part of the class and what are the main points of the class.

The results from comparing the traditional and blended courses in an introductory financial accounting course over 2009 - 2010 suggest that although the blended teaching model does not directly improves the student final performance, it improves the student final performance through in class activities after controlling for prior GPA, math grade, gender, transfer, program, level, homework grade, online quiz grade, and in-class exercise grade.

This study contributes to the blended learning research by providing a particular way to implement the blended learning. In particular, it suggests that the lower level of education objectives be learned / previewed by students online before they come to class and through online tests. This leaves limited in-class time to more complicated discussions and case studies. Prior studies has examines whether blended learning can improve students' learning outcomes, such as Dowling et al. (2003) and Keller et al. (2009). However, their designs of blended course are different from this study. For example, in Keller et al. (2009), the design is to have students meet once per week for lecture, and then students work as teams on problems outside of classroom and submit solutions to the instructor electronically.

The remainder of the paper is organized as follows. Section 2 discusses previous research and hypotheses. Section 3 introduces the blended course design and assessment. Section 4 provides the empirical model and sample used in the study. Then section 5 shows the results and section 6 provides the conclusion.

\section{PREVIOUS RESEARCH AND HYPOTHESES}

There have been extensive studies attempted to examine whether blended learning can enhance students' learning outcomes. For example, US Department of Education (2009) uses meta-analysis, synthesizes the results of more than a thousand empirical studies of online learning from 1996 through July 2008 and concludes that on average, instructions combining online and face-to-face elements had a larger advantage relative to purely face-toface instruction than did purely online instruction. Prior studies on student's performance in traditional and blended class in accounting area have shown mixed results. Some studies report no significant difference between traditional teaching model and blended teaching model, e.g., Keller et al. (2009). On the other hand, other studies find significant positive student performance for blended course, e.g., Dowling et al. (2003) and Jones and Chen (2008).

Dowling et al. (2003) examine whether the learning outcomes of students differ in traditional face-to-face lecture/tutorial teaching model and hybrid flexible delivery model for Accounting Information System course in 2000 and 2001. The hybrid class includes a combination of 3-hour face-to-face interactive practical work every two weeks and multimedia resources including a Netshow CD-Rom that contains PowerPoint slides with narration attached and the WebCT discussion board. There were no face to face lecture, and the students choose the time and place they listen to the electronic lectures. The authors find that students' overall course grade and final exam grade are significantly positive for the hybrid section after controlling for prior academic performance, age, gender, mode of study, and campus location. However, the midterm exam grade is significantly negative for the hybrid section. The authors discuss that the students may need time to adapt to the hybrid course.

Potter and Johnston (2006) examine the association between student use of MarlinaLS ${ }^{\mathrm{TM}}$ online system and the learning outcomes achieved by students in a major second year undergraduate Cost Management course during 2002-2003. They find that the logarithm of student usage of MarlinaLS ${ }^{\mathrm{TM}}$ system during the semester is significantly positively related to student final examination performance after controlling for grades from prerequisite accounting course, gender, international status, and the interaction of logarithm of MarlinaLS ${ }^{\mathrm{TM}}$ system and gender and logarithm of MarlinaLS ${ }^{\mathrm{TM}}$ system and international status. 
Keller et al. (2009) compare student performance in traditional and hybrid section of the Principles of Managerial Accounting course after controlling for other factors that could affect student performance. The hybrid class meets once per week in person and once per week via the web. The students meet for lecture for the first day, and then work as teams on problems outside of the classroom for the second day and submit solutions to the instructor electronically by the end of the day. The instructor posted solutions via web by the next day. The authors find that academic performance of hybrid section was not significantly different from the traditional section after controlling for prerequisite course grade, gender, transfer, and SAT score.

Jones and Chen (2008) compare the students' survey responses in a blended-learning section $(\mathrm{n}=30)$ and a traditional classroom section $(n=34)$ of an introductory MBA accounting course to assess the relative effectiveness and overall students' satisfaction of the two delivery model. The blended class includes a combination of four faceto-face meetings during the semester and two hours per week online meetings during the semester. The authors find that blended learning students are significantly more likely to indicate that the instructor provides prompt feedback outside of class, instructor is available to answer their question, and instructor keeps students informed of their progress. However, they find that blended class students are significantly less likely to indicate that instructor explains the material in an interesting manner, and the students are less satisfied with the interaction between instructor and students. In addition, they find that blended class students are more satisfied with the group work than traditional class. In terms of the effectiveness of the course delivery, they find that $90 \%$ of the students favored traditional in-class delivery.

Table 1 compares the models and findings for the above studies. The above studies did not examine whether blended course can enhance students' active learning by providing a platform to motivate (test) students' lower-level education (such as Understand and Comprehension) prior to class, in-depth discussion in class, and additional assessment after class. When students are required to learn some content that is low-level before they come to the classroom, the role as an instructor changes and the students are motivated to actively involve and take more responsibility of the learning process. This study hypothesizes that switching from a traditional teaching model to a blended teaching model will motivate the students and enhance students' final course performances.

In addition, it is expected that better preparation with before-class quiz will leave extra class time to engage in application, analysis, synthesis, and evaluation, and enable students to better understand the in-class exercises and case problems, which will help students' course performances.

The hypotheses are stated as follows:

Hypothesis 1: A blended teaching model that incorporating online before-class and after-class activities directly improves the student final performance.

Hypothesis 2: A blended teaching model that incorporating online before-class and after-class activities improves the student final performance through in class activities.

\section{COURSE DESIGN}

Principles of Accounting I (ACT 211) is an introductory financial accounting course and is required for all students and all degrees offered by the business school. In addition, a portion of students come from other colleges such as Arts \& Sciences, Liberal Arts, and Engineering. Therefore, the students range from freshman to senior, and some of them are not business major. For a large portion of the students, this class will be the only accounting course that they take. Among these students, many tend to have negative attitudes towards accounting (Mladenovic (2000)).

Principles of Accounting I provides students a basic understanding of accounting and how to use accounting information to make business decisions. Topics covered in the course include basic accounting concepts and procedures through the analysis, classification, recording, and summarizing of business transactions; preparation and analysis of the major financial statements; and recording and reporting the major components of the statements, such as cash, receivables, inventories, long-lived assets, payables, notes, bonds, equity, and investments. 
Table 1. Previous Studies on Traditional and Blended Model

\begin{tabular}{|c|c|c|c|c|}
\hline & Course & Traditional Model & Blended model & Finding \\
\hline $\begin{array}{l}\text { Dowling } \\
\text { et al. } \\
\text { (2003) }\end{array}$ & $\begin{array}{l}\text { Accounting } \\
\text { Information } \\
\text { System }\end{array}$ & $\begin{array}{l}\text { 3-hour session per week } \\
\text { including lectures and practice } \\
\text { problems; Flexicomm (similar } \\
\text { to WebCT) discussion board } \\
\text { was used. }\end{array}$ & $\begin{array}{l}\text { A combination of 3-hour face-to-face interactive } \\
\text { seminar every two weeks and multimedia } \\
\text { resources including a Netshow CD-Rom that } \\
\text { contains PowerPoint slides with narration attached } \\
\text { and the WebCT discussion board. }\end{array}$ & $\begin{array}{l}\text { Students' overall course grade and final exam grade are significantly } \\
\text { positive for the hybrid section after controlling for prior academic } \\
\text { performance, age, gender, mode of study, and campus location. However, } \\
\text { the midterm exam grade is significantly negative for the hybrid section. }\end{array}$ \\
\hline $\begin{array}{l}\text { Keller et } \\
\text { al. (2009) }\end{array}$ & $\begin{array}{l}\text { Principles of } \\
\text { Managerial } \\
\text { Accounting }\end{array}$ & $\begin{array}{l}\text { Two days per week, with one } \\
\text { class period being a lecture day } \\
\text { and the second class period } \\
\text { being used for advanced } \\
\text { problem solving. Students } \\
\text { work in teams and instructor } \\
\text { analyze the problem and } \\
\text { provide solution in class. } \\
\text { Oncourse is used similarly as } \\
\text { for hybrid course. }\end{array}$ & $\begin{array}{l}\text { The hybrid class meets once per week in person } \\
\text { and once per week via the web. The students meet } \\
\text { for lecture for the first day, and then work as teams } \\
\text { on problems outside of the classroom for the } \\
\text { second day and submit solutions to the instructor } \\
\text { electronically by the end of the day. The instructor } \\
\text { posted solutions via web by the next day. The } \\
\text { traditional and the hybrid section have the same } \\
\text { instructor, same lecture delivered, same problems } \\
\text { covered, same midterm, final and web-based } \\
\text { practice quizzes. }\end{array}$ & $\begin{array}{l}\text { The academic performance of hybrid section was not significantly different } \\
\text { from the traditional section after controlling for prerequisite course grade, } \\
\text { gender, transfer, and SAT score. }\end{array}$ \\
\hline $\begin{array}{l}\text { Potter and } \\
\text { Johnston } \\
(2006)\end{array}$ & $\begin{array}{l}\text { Second year } \\
\text { undergraduate } \\
\text { Cost Management } \\
\text { course at } \\
\text { University of } \\
\text { Melbourne, } \\
\text { Australia } \\
\end{array}$ & $\begin{array}{l}\text { Two 1-hour lectures per week, } \\
\text { one 1-hour tutorial, and one 1- } \\
\text { hour optional workshop. } \\
\text { Workshop and tutorials include } \\
\text { paper-based exercises drawn } \\
\text { from textbook and other } \\
\text { sources. }\end{array}$ & $\begin{array}{l}\text { The one 1-hour workshop was replaced by } \\
\text { MarlinaLS }{ }^{\mathrm{TM}} \text { online learning system that provides } \\
\text { practical-based problems and immediate feedback. } \\
\text { MarlinaLS }{ }^{\mathrm{TM}} \text { also contains on-line tutor, and a } \\
\text { multi-choice, self-paced, revision tool. }\end{array}$ & $\begin{array}{l}\text { The logarithm of student usage of MarlinaLS } S^{\mathrm{TM}} \text { system during the semester } \\
\text { is significantly positively related to student final examination performance } \\
\text { after controlling for grades from prerequisite accounting course, gender, } \\
\text { international status, and the interaction of logarithm of MarlinaLS }{ }^{\mathrm{TM}} \\
\text { system and gender and logarithm of MarlinaLS } S^{\mathrm{TM}} \text { system and international } \\
\text { status over the period 2002-2003. }\end{array}$ \\
\hline $\begin{array}{l}\text { Love and } \\
\text { Fry (2006) }\end{array}$ & $\begin{array}{l}\text { First year } \\
\text { undergraduate } \\
\text { accounting } \\
\text { students at a UK } \\
\text { business school. }\end{array}$ & & $\begin{array}{l}\text { Lectures and other course materials are available } \\
\text { online, use discussion board to ask questions, } \\
\text { online testing, and announcement. }\end{array}$ & $\begin{array}{l}\text { Few students view the web-based environment as a "springboard" to } \\
\text { enhance education performance. The online version of teaching materials } \\
\text { does not motivate students to either attend face-to-face sessions or to use } \\
\text { the online materials to engage in an independent and deep approach to } \\
\text { learning. On the other hand, the web-based learning can be viewed as } \\
\text { "safety net" that provides support mechanism for existing teaching } \\
\text { methods. The findings do not support existing literature that the web- } \\
\text { based environment contributes to improved relationships in terms of } \\
\text { communication between learner-tutor and learner-learner. }\end{array}$ \\
\hline $\begin{array}{l}\text { Jones and } \\
\text { Chen } \\
\text { (2008) }\end{array}$ & $\begin{array}{l}\text { Introductory MBA } \\
\text { accounting }\end{array}$ & $\begin{array}{l}\text { Meet twice a week for } 75 \\
\text { minutes each including lecture } \\
\text { and case discussions. }\end{array}$ & $\begin{array}{l}\text { The blended class includes (1) } 4 \text { face-to-face } \\
\text { meetings during the semester, which include } \\
\text { lecture and case discussions and (2) } 2 \text {-hour online } \\
\text { meetings each week, focusing on specific student } \\
\text { questions emailed to the instructor prior to online } \\
\text { meetings. }\end{array}$ & $\begin{array}{l}\text { Blended learning students are significantly more likely to indicate that the } \\
\text { instructor provides prompt feedback outside of class, is available to answer } \\
\text { their question, and keeps students informed of their progress. However, the } \\
\text { blended class students are significantly less likely to indicate that instructor } \\
\text { explains the material in an interesting manner, and the students are less } \\
\text { satisfied with the interaction between instructor and students. }\end{array}$ \\
\hline $\begin{array}{l}\text { Basioudis } \\
\text { and de } \\
\text { Lange } \\
(2009)\end{array}$ & $\begin{array}{l}\text { Introduction to } \\
\text { Financial } \\
\text { Accounting in UK. }\end{array}$ & & $\begin{array}{l}\text { 2-hour lecture per week and 1-hour tutorial per } \\
\text { week. The web-based class includes (1) provisions } \\
\text { of lecture notes handouts, (2) bulletin board, (3) } \\
\text { self-tests not counted towards final course mark, } \\
\text { (4) online assessments that count towards final } \\
\text { mark, (5) use of other blackboard tools such as } \\
\text { chat room, (6) announcements and solutions. }\end{array}$ & $\begin{array}{l}\text { They find that student satisfaction in overall course evaluations is } \\
\text { associated with five design features, including usefulness and availability } \\
\text { of lecture notes, online assessment, model answers, and online chat. The } \\
\text { results are not affected by the student background demographics such as } \\
\text { gender, age, mode of study (full/part-time), degree, religion, ethnicity and } \\
\text { country of legal nationality. }\end{array}$ \\
\hline
\end{tabular}


In fall 2009 and spring 2010, the ACT 211 was delivered using a relatively traditional teaching model that involved two 75-minute sections each week, supplemented by WebCT. Lecture slides are posted on WebCT for student convenience. Announcements are made though email and WebCT. Homework solutions are posted after returning the students' assignments. Student grades are updated each week on WebCT. The instructor collects the homework assignments and hands back after grading them. The face-to-face meeting includes lecture discussion and in-class exercises. In fall 2010, the ACT 211 was granted Davis grant for Implementation of Blended Learning for the Improvement of Student Learning (IBIS) and delivered using the blended learning model. The blended class includes a combination of same face-to-face meetings and blended components, including online homework, beforeclass quizzes, real company discussion board, and after-class discussion board. Both blended and traditional classes are taught by the same instructor using same materials for two semesters. Both classes use the same textbook, homework assignments and publisher's online quizzes. The descriptions of blended components are as follows.

Before Class Quizzes. The purpose of the before-class quizzes is to ensure that students read the slides and textbook before they come to class. The students are required to work on before-class quizzes for each chapter based on their reading and understanding of textbook and PowerPoint slides posted on WebCT. The quizzes are normally lower-level learning, knowledge- and comprehension-based multiple choice questions. These quizzes are made unavailable after class starts.

After Class Online Homework Assignments and Online Quizzes. The purpose of the after-class homework assignments and online quizzes is to ensure students continue their contact with the material. In all three semesters, the students are required to do the same homework assignments and publisher's online quizzes. In fall 2009 and spring 2010, students need to turn in the homework assignments and wait for the instructor to grade them and give back. In fall 2010, the homework assignments were done through McGraw-Hill Homework Manager. The students receive immediate feedback automatically and they can correct the homework when needed. In fall 2009 and spring 2010, students are required to do the publisher's online quizzes. In fall 2010, the students are required to do the same online quizzes linked through WebCT.

After Class Comments Postings. The students reflect their learning through the after-class comments postings on the WebCT discussion board. The posting includes two components: (1) what was the most confusing part of the chapter, and (2) what was the main point of the chapter. The students are required to post after-class comments after each chapter. Students are also required to respond to at least 2 of their classmates' postings.

Company Case and Project Postings. The purpose of the assignments is to apply the knowledge learned in class to the real world to foster high-level education objectives such as Analysis, Synthesis, and Evaluation. Students are required to select their own company and find the company's financial statements from SEC website and post company financial statement analysis related to each chapter on Discussion Board as groups. The company case and project are part of the homework assignments that required turning in under traditional teaching model.

Student Performance. Assessment of performance in the blended class as based on the same homework assignments (turned in via Homework Manager), in-class exercises, in-class participation, publisher's online quizzes (turned in using WebCT), a company social responsibility writing project, two midterm examinations, and a final examination, as well as the online components including before-class quizzes, after-class comments postings, and company case and project postings. In comparison, assessment of performance in the traditional class was based on homework assignments (turned-in as hardcopy), in-class exercises, class participation, publisher's online quizzes (from publisher's website), a company social responsibility writing project, two midterm examinations, and a final examination.

The format of the midterm and final examinations was 44 and 66 multiple choice questions. This increases the comparability of the student performance during two years. Table 2 present a comparison of the two teaching models. 
Table 2. Traditional and Blended Course Models

\begin{tabular}{|c|c|c|}
\hline & $\begin{array}{l}\text { Traditional Teaching Model } \\
\text { (Fall } 2009 \text { and spring 2010) }\end{array}$ & $\begin{array}{l}\text { Blended Course Model } \\
\text { (fall 2010, one section) }\end{array}$ \\
\hline Contact hours & Tuesday and Thursday 75 minutes each section & Tuesday and Thursday 75 minutes \\
\hline Class size & 40- 50 each section & 51 \\
\hline WebCT & $\begin{array}{l}\text { Lecture slides are posted on WebCT for student } \\
\text { convenience. Announcements are made though email } \\
\text { and WebCT. Homework solutions are posted after } \\
\text { returning the students' assignments. Student grades are } \\
\text { updated each week on WebCT. }\end{array}$ & $\begin{array}{l}\text { (1) Lecture slides are posted on WebCT. } \\
\text { Announcements are made though email and } \\
\text { WebCT. Student grades are updated each week } \\
\text { on WebCT. (2) WebCT also includes before-class } \\
\text { quizzes, after-class comments on discussion } \\
\text { board, and company case analysis on discussion } \\
\text { board. Homework from Homework Manager and } \\
\text { publisher's online quizzes are linked to WebCT. }\end{array}$ \\
\hline Class section & $\begin{array}{l}\text { Lecture discussion, problem solving including in-class } \\
\text { exercises and homework assignments. }\end{array}$ & $\begin{array}{l}\text { In-depth lecture discussion, problem solving } \\
\text { including case-based in-class exercises and } \\
\text { homework assignments. }\end{array}$ \\
\hline Assessment & $\begin{array}{l}\text { Student performance are based on } \\
\text { homework assignments (The instructor collects the } \\
\text { homework assignments and hands back after grading } \\
\text { them), in-class exercises, in-class participation, } \\
\text { publisher's online quizzes, a company social } \\
\text { responsibility writing project, two midterm examination, } \\
\text { and a final exam. }\end{array}$ & $\begin{array}{l}\text { Student performance are based on homework } \\
\text { assignment (turned-in online via Homework } \\
\text { Manager), in-class exercises and case problems, } \\
\text { in-class participation, publisher's online quizzes } \\
\text { (linked from WebCT), a company social } \\
\text { responsibility writing project, two midterm } \\
\text { examinations, and a final exam, as well as the } \\
\text { online components including before-class quizzes, } \\
\text { after-class comments postings, and company case } \\
\text { and project postings. }\end{array}$ \\
\hline
\end{tabular}

\section{RESEARCH DESIGN}

\subsection{Empirical model}

The study examines whether blended teaching model that introduces lower-level education online learned by students before they come into class will enhance student performance as compared to traditional course. The empirical model is as follows.

Grade $=a_{0}+\alpha_{1}$ Type $+\alpha_{2}$ Gender $+\alpha_{3}$ Transfer $+\alpha_{4}$ Mathgrade $+\alpha_{5}$ PriorGPA $+\alpha_{6}$ BusinessProg $+\alpha_{7}$ Level $+\alpha_{8}$

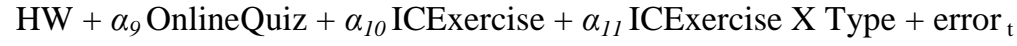

where,

Grade $=$ final course grade or final exam grade in financial accounting course.

Type $=1$ if blended, 0 if traditional.

Gender $=1$ if male, 0 if female.

Transfer $=1$ if transfer student, 0 freshman start.

Mathgrade $=$ Math 103 grade, math course taken when first entering college.

PriorGPA $=$ prior grade point average (GPA) before taking financial accounting course.

BusinessProg $=1$ if business program, 0 otherwise.

Level $=1$ if sophomore, 0 otherwise.

HW $=$ Homework grade for the course.

OnlineQuiz $=$ publisher's online quiz grade for the course.

ICExercise $=$ In class exercise, case and project for the course.

Hypothesis 1 predicts that blended teaching model directly improves the student final performance, which suggests that $\alpha_{1}>0$. Hypothesis 2 predicts that blended teaching model improves the student final performance through in depth in class activities, i.e., $\alpha_{11}>0$. 


\subsection{Sample}

The sample includes students who completed Principles of Accounting I in 2009 and 2010. In fall 2009, 40 out of 51 students completed the course; in spring 2010, 82 out of 88 students completed the course; and in fall 2010, 51 out of 52 students completed the course. Following Dowling et al. (2003), a student was classified as completed the course if he/she had attempted the final examination. There are 3 students repeating the course, who were eliminated from the sample. In addition, 39 students without math grade or prior GPA were also dropped from the sample. The final sample includes 128 students: 30 from fall 2009, 58 from spring 2010, and 40 from fall 2010. Fall 2009 and spring 2010 use traditional teaching model, and fall 2010 uses blended teaching model.

The student information including academic affiliations, gender, and prior grade point average (GPA) are presented in Table 3. The students came from a variety of academic backgrounds, and varied for traditional class and hybrid class. There are $27 \%$ in Arts and Science (24) in traditional class, and $0.5 \%$ (2) in hybrid class. Business major is 53/88 (53\%) in traditional class, and 38/40 (95\%) in hybrid class. Male is 59/88 (67\%) in traditional class, and $30 / 40(75 \%)$ in hybrid class.

Table 3. Student Information for Traditional and Blended Courses

\begin{tabular}{|l|c|c|}
\hline \multicolumn{1}{|c|}{ Traditional } \\
\hline By academic affiliation & & Blended \\
\hline Arts and Science & 24 & 2 \\
\hline Engineering & 10 & 0 \\
\hline Non Degree Undergraduate & 1 & 38 \\
\hline Business & 53 & 22 \\
\hline Business Undeclared & 23 & 4 \\
\hline Marketing & 13 & 5 \\
\hline Accounting & 8 & 2 \\
\hline Finance & 3 & 4 \\
\hline Management Information System & 3 & 1 \\
\hline Operations Management & 2 & 0 \\
\hline Human Resource Management & 1 & 40 \\
\hline Total & 88 & \\
\hline & & \\
\hline By Level & & \\
\hline Freshman & 15 & 20 \\
\hline Sophomore & 62 & 19 \\
\hline Junior & 7 & 1 \\
\hline Senior & 4 & \\
\hline & & \\
\hline By Gender & & \\
\hline Male & 59 & \\
\hline Female & 29 & \\
\hline Total & 88 & \\
\hline
\end{tabular}

\begin{tabular}{|l|c|c|c|c|c|c|}
\hline & \multicolumn{2}{|c|}{ Traditional } & \multicolumn{2}{c|}{ Blended } & \multicolumn{2}{c|}{ Wilcoxon } \\
\cline { 2 - 7 } & Mean & Median & Mean & Median & $\begin{array}{c}\text { Mean t-test } \\
\text { (t-value) }\end{array}$ & $\begin{array}{c}\text { Median test } \\
\text { (z-value) }\end{array}$ \\
\hline Overall mark & 75.150 & 74.320 & 76.335 & 78.380 & -0.489 & -0.699 \\
\hline Final exam & 69.042 & 69.350 & 70.524 & 71.775 & -0.434 & -0.460 \\
\hline Prior GPA & 2.652 & 2.589 & 2.700 & 2.843 & -0.415 & -0.591 \\
\hline Math grade & 2.836 & 3.000 & 2.630 & 2.85 & 1.162 & 0.997 \\
\hline Homework & 5.728 & 6.125 & 5.730 & 6.593 & -0.006 & -0.931 \\
\hline Online quiz & 4.509 & 5.000 & 3.664 & 5 & $3.197 * * *$ & 1.587 \\
\hline ICExercise & 5.891 & 6.150 & 6.183 & 6.500 & -0.980 & -1.090 \\
\hline
\end{tabular}


The descriptive statistics on final course grades and final examination grades suggest that although the mean (70.524 and 76.335) and median (71.775 and 78.38) for blended learning are higher than traditional class mean (69.042 and 75.15) and median (69.35 and 74.32), they are not statistically significant. The control variables PriorGPA, Mathgrade, homework, and ICExercise are not significantly different. The mean student grades on Onlinequiz for traditional course are found to be higher than those in blended course.

\section{REGRESSION RESULTS}

Table 4 presents regression analysis for final examination grade and total course grade for traditional teaching model and blended teaching model, respectively. Model 1 indicates that final examination grades are significantly related to Gender, Mathgrade, and PriorGPA for traditional teaching model, while ICExercise and PriorGPA are most important for blended teaching model. Model 2 results show that final course grades are significantly related to Gender, Mathgrade, PriorGPA, Homework and ICExercises for traditional teaching model and Transfer, Online Quiz and ICExercises for blended teaching model. The above results suggest that the determinants of the two types of teaching models can be quite different. In particular, Gender is found to be positively related to final examination and course grades in traditional teaching model, and statistically insignificant in blended teaching model. This suggests that student learning styles may differ based on gender. In addition, Mathgrade and PriorGPA are significant determinants of traditional teaching model. However, they are not statistically significant in the blended teaching model.

Table 4. Regression Results for Traditional and Blended Models

\begin{tabular}{|c|c|c|c|c|}
\hline & \multicolumn{2}{|c|}{ Model 1 (final exam grade) } & \multicolumn{2}{|c|}{ Model 2 (final course grade) } \\
\hline Dependent variable & $\begin{array}{l}\text { Traditional model } \\
\text { (robust) }\end{array}$ & $\begin{array}{l}\text { Blended model } \\
\text { (robust) }\end{array}$ & $\begin{array}{c}\text { Traditional Model } \\
\text { (robust) }\end{array}$ & $\begin{array}{l}\text { Blended Model } \\
\text { (robust) }\end{array}$ \\
\hline Intercept & $\begin{array}{l}2.061 \\
(0.18) \\
\end{array}$ & $\begin{array}{c}-11.003 \\
(-0.72) \\
\end{array}$ & $\begin{array}{c}22.119 * * * \\
(4.41)\end{array}$ & $\begin{array}{l}1.411 \\
(0.14) \\
\end{array}$ \\
\hline Gender & $\begin{array}{c}16.817 * * * \\
(4.25) \\
\end{array}$ & $\begin{array}{l}2.329 \\
(0.40) \\
\end{array}$ & $\begin{array}{c}4.811 * * * \\
(2.70)\end{array}$ & $\begin{array}{l}0.096 \\
(0.02) \\
\end{array}$ \\
\hline Transfer & $\begin{array}{l}6.412 \\
(1.26)\end{array}$ & $\begin{array}{l}12.111 \\
(1.29)\end{array}$ & $\begin{array}{l}2.735 \\
(1.20) \\
\end{array}$ & $\begin{array}{c}17.025^{* *} \\
(2.69)\end{array}$ \\
\hline Math grade & $\begin{array}{c}5.956 * * \\
(2.59) \\
\end{array}$ & $\begin{array}{l}1.018 \\
(0.40) \\
\end{array}$ & $\begin{array}{c}2.318^{* * *} \\
(2.24) \\
\end{array}$ & $\begin{array}{l}1.809 \\
(1.07)\end{array}$ \\
\hline Prior GPA & $\begin{array}{c}12.996 * * * * \\
(3.21)\end{array}$ & $\begin{array}{l}9.949 * * \\
(2.08)\end{array}$ & $\begin{array}{c}8.897 * * * \\
(4.88)\end{array}$ & $\begin{array}{l}4.506 \\
(1.40)\end{array}$ \\
\hline Program & $\begin{array}{l}4.474 \\
(1.31)\end{array}$ & $\begin{array}{l}9.057 \\
(0.80)\end{array}$ & $\begin{array}{l}3.028^{*} \\
(1.97)\end{array}$ & $\begin{array}{l}8.559 \\
(1.13)\end{array}$ \\
\hline Level & $\begin{array}{l}3.072 \\
(0.84) \\
\end{array}$ & $\begin{array}{l}-3.037 \\
(-0.60) \\
\end{array}$ & $\begin{array}{l}-0.295 \\
(-0.18) \\
\end{array}$ & $\begin{array}{l}-1.846 \\
(-0.54) \\
\end{array}$ \\
\hline Homework & $\begin{array}{l}0.834 \\
(0.64) \\
\end{array}$ & $\begin{array}{l}-0.882 \\
(-0.63) \\
\end{array}$ & $\begin{array}{c}1.585 * * * \\
(2.72)\end{array}$ & $\begin{array}{l}1.003 \\
(1.06) \\
\end{array}$ \\
\hline Online Quiz & $\begin{array}{l}-1.478 \\
(-0.84) \\
\end{array}$ & $\begin{array}{l}-0.763 \\
(-0.60) \\
\end{array}$ & $\begin{array}{l}0.286 \\
(0.36) \\
\end{array}$ & $\begin{array}{c}1.958^{* * *} \\
(2.29)\end{array}$ \\
\hline IC Exercise & $\begin{array}{l}0.153 \\
(0.11) \\
\end{array}$ & $\begin{array}{c}7.962 * * * \\
(3.09) \\
\end{array}$ & $\begin{array}{c}1.252^{* *} \\
(2.05) \\
\end{array}$ & $\begin{array}{c}5.891 * * * \\
(3.39) \\
\end{array}$ \\
\hline Adjusted R ${ }^{2}$ & 0.412 & 0.486 & 0.664 & 0.705 \\
\hline $\mathbf{F}$ & 7.77 & 5.1 & 20.13 & 11.36 \\
\hline Significance & $0.000 * * *$ & $0.000 * * *$ & $0.000 * * *$ & $0.000 * * *$ \\
\hline observation & 88 & 40 & 88 & 40 \\
\hline
\end{tabular}

Notes: $\quad$ The variables are defined as follows. Gender $=1$ if male, 0 if female. Transfer $=1$ if transfer student, 0 freshman start. Mathgrade = Math 103 grade, math course taken when first entering college. PriorGPA = prior grade point average (GPA) before taking financial accounting course. BusinessProg $=1$ if business program, 0 otherwise. Level $=1$ if sophomore, 0 otherwise. HW = Homework grade for the course. Online Quiz = publisher's online quiz grade for the course. ICExercise $=$ In class exercise, case and project for the course. The t statistics are in parenthesis. $* * * / * * / *$ denote the significance at the $0.01 / 0.05 / 0.10$ level. 
Table 5 provides the regression results of final examination grade and final course grade on Type and interaction of Type and ICExercise after controlling for gender, transfer status, math grade, prior GPA academic affiliation, academic level, homework, online quizzes, and ICexercises. The results show that Type is not statistically significant, which does not support hypothesis 1. The interaction of Type and ICExercise is significantly associated with both final examination grade and final course grade. This result support the hypothesis 2 that blended teaching model improves the student final performance through in depth in class activities.

Table 5. Regression Results on Interaction of Type and In-Class Activity

\begin{tabular}{|c|c|c|}
\hline Dependent variable & $\begin{array}{c}\text { Model 1 } \\
\text { (final exam grade) }\end{array}$ & $\begin{array}{c}\text { Model 2 } \\
\text { (final course grade) }\end{array}$ \\
\hline Intercept & $\begin{array}{c}17.563^{* *} \\
(1.99)\end{array}$ & $\begin{array}{c}22.138 * * * \\
(5.22)\end{array}$ \\
\hline Type & $\begin{array}{l}-4.679 \\
(-1.46) \\
\end{array}$ & $\begin{array}{l}-1.432 \\
(-0.93) \\
\end{array}$ \\
\hline Gender & $\begin{array}{c}10.810^{* * * *} \\
(3.49)\end{array}$ & $\begin{array}{l}3.989 * * * \\
(2.68)\end{array}$ \\
\hline Transfer & $\begin{array}{l}5.475 \\
(1.28)\end{array}$ & $\begin{array}{c}4.321^{* * *} \\
(2.10)\end{array}$ \\
\hline Mathgrade & $\begin{array}{c}3.528^{* * *} \\
(2.12)\end{array}$ & $\begin{array}{c}1.734^{* * *} \\
(2.17)\end{array}$ \\
\hline PriorGPA & $\begin{array}{c}13.189 * * * \\
(4.42)\end{array}$ & $\begin{array}{c}8.910 * * * \\
(6.21)\end{array}$ \\
\hline Program & $\begin{array}{l}4.708 \\
(1.51)\end{array}$ & $\begin{array}{c}3.339 * * \\
(2.23)\end{array}$ \\
\hline Level & $\begin{array}{c}-11.026^{*} \\
(-1.98)\end{array}$ & $\begin{array}{l}-2.921 \\
(-1.09)\end{array}$ \\
\hline Homework & $\begin{array}{l}0.055 \\
(0.06)\end{array}$ & $\begin{array}{c}1.384 * * * \\
(3.26)\end{array}$ \\
\hline OnlineQuiz & $\begin{array}{l}-1.515 \\
(-1.40)\end{array}$ & $\begin{array}{l}0.966^{*} \\
(1.86)\end{array}$ \\
\hline ICExercise & $\begin{array}{l}0.562 \\
(0.46)\end{array}$ & $\begin{array}{c}1.227 * * \\
(2.09)\end{array}$ \\
\hline ICExercise X Type & $\begin{array}{c}3.984 * * \\
(2.09)\end{array}$ & $\begin{array}{c}3.171^{* * * *} \\
(3.47)\end{array}$ \\
\hline Adjusted $\mathrm{R}^{2}$ & 0.383 & 0.71 \\
\hline $\mathrm{F}$ & 8.17 & 29.23 \\
\hline Significance & $0.000 * * *$ & $0.000^{* * * *}$ \\
\hline observation & 128 & 128 \\
\hline
\end{tabular}

Notes: $\quad$ The variables are defined as follows. Gender $=1$ if male, 0 if female. Transfer $=1$ if transfer student, 0 freshman start. Mathgrade $=$ Math 103 grade, math course taken when first entering college. PriorGPA $=$ prior grade point average (GPA) before taking financial accounting course. BusinessProg $=1$ if business program, 0 otherwise. Level $=1$ if sophomore, 0 otherwise. $\mathrm{HW}=$ Homework grade for the course. Online Quiz $=$ publisher's online quiz grade for the course. ICExercise $=$ In class exercise, case and project for the course. ICExercise X Type is calculated as (ICExercise - mean of ICExercise) X Type to avoid multicollinearity problem. The t statistics are in parenthesis. $* * * / * * / *$ denote the significance at the $0.01 / 0.05 / 0.10$ level.

\section{CONCLUSION}

Blended course combines traditional delivery with online teaching resources to enhance the quality of student learning. Recently, studies have examined whether blended learning model would enhance the student performance as compared to traditional learning model. This study adds to this literature by examining whether a specific design of blended course, i.e., introduces lower-level education online learned by students before they come into class, will enhance student performance as compared to traditional course. The paper finds that after controlling for gender, transfer status, math grade, prior GPA, academic affiliation, academic level, although switching from a traditional teaching model to a blended teaching model does not directly improve the student final performance, it improves the student final performance through in-depth in class activities. 


\section{ACKNOWLEDGEMENTS}

The author gratefully acknowledges the Davis grant for Implementation of Blended Learning for the Improvement of Student Learning (IBIS) from University of Massachusetts Dartmouth.

\section{AUTHOR INFORMATION}

Chan Du is Assistant Professor of Accounting at University of Massachusetts Dartmouth. She holds a D.B.A in accounting from Boston University. She teaches principles of accounting, intermediate accounting, and financial statement analysis courses at University of Massachusetts Dartmouth. She has published article in Journal of International Money and Finance. E-mail: cdu@umassd.edu

\section{REFERENCES}

1. Basioudis, Ilias G., and Paul A. de Lange (2009). An Assessment of the Learning Benefits of Using a WebBased Learning Environment When Teaching Accounting. Advances in Accounting, incorporating Advances in International Accounting 25:13-19.

2. Bloom, B. 1956. Taxonomy of Educational Objectives. In Handbook I: The Cognitive Domain. New York: David McKay, Co. Inc.

3. Dowling, Carlin, Jayne M. Godfrey, and Nikole Gyles (2003). Do Hybrid Flexible Delivery Teaching Methods Improve Accounting Students' Learning Outcomes? Accounting Education 12 (4):373-391.

4. Jones, Keith Thomas, and Clement C. Chen (2008). Blended Learning in a Graduate Accounting Course: Student Satisfaction and Course Design Issues. The Accounting Educators' Journal 18:15-28.

5. Keller, J. Howard, John M. Hassell, Sally A. Webber, and James N. Johnson (2009). A Comparison of Academic Performance in Traditional and Hybrid Sections of Introductory Managerial Accounting. Journal of Accounting Education 27 (3):147-154.

6. Love, Nia, and Nadine Fry (2006). Accounting Students' Perceptions of a Virtual Learning Environment: Springboard or Safety Net? Accounting Education: an international journal 15 (2):151-166.

7. Mladenovic, R. (2000). An Investigation into Ways of Challenging Introductory Accounting Student's Negative Perceptions of Accounting. Accounting Education 9 (2):135-155.

8. Potter, Bradley N., and Carol G. Johnston (2006). The Effect of Interactive on-Line Learning Systems on Student Learning Outcomes in Accounting. Journal of Accounting Education 24:16-34.

9. Shibley, Ike. 2009. 10 Ways to Improve Blended Learning Course Design. In Magna Publications Online Seminar, edited by B. Snyder.

10. US Department of Education, Office of Planning Evaluation and Policy Development. Evaluation of Evidence-Based Practices in Online Learning: A Meta-Analysis and Review of Online Learning Studies 2009 [cited. Available from www.ed.gov/about/offices/list/opepd/ppss/reports.html.

11. Utts, Jessica, Barbara Sommer, Curt Acredolo, Michael W. Maher, and Harry R. Matthews (2003). A Study Comparing Traditional and Hybrid Internet-Based Instruction in Introductory Statistics Classes. Journal of Statistics Education 11 (3). 